\title{
Arsenic in Sediments, Soil and Plants in a Remediated Area of the Iron Quadrangle, Brazil, and its Accumulation and Biotransformation in Eleocharis geniculata
}

\author{
Maria Ângela de B. C. Menezes, ${ }^{1}$ Ingrid Falnoga, ${ }^{2}$ Zdenka Šlejkovec, ${ }^{2}$ \\ Radojko Jaćimović, ${ }^{2}$ Nilton Couto, ${ }^{3}$ Eleonora Deschamps ${ }^{4}$ and Jadran Faganeli ${ }^{5}{ }^{*}$ \\ ${ }^{1}$ Nuclear Technology Development Centre/Brazilian Commission for Nuclear Energy (CDTN/CNEN), \\ Division for Analytical Techniques, Caixa Postal 941, CEP 30161-970, Belo Horizonte, Minas Gerais, Brazil \\ ${ }^{2}$ Jožef Stefan Institute, Department of Environmental Sciences, Jamova cesta 39, SI-1000 Ljubljana, Slovenia \\ ${ }^{3}$ Fundação Ezequiel Dias (FUNED), Rua Conde Pereira Carneiro, 80, Gameleira, CEP 30510-010, \\ Belo Horizonte, Minas Gerais, Brazil \\ ${ }^{4}$ FUMEC (Universidade Fundação Mineira de Educação e Cultura), Rua Cobre, 200, CEP: 30.310-190 \\ Belo Horizonte, Minas Gerais, Brazil \\ ${ }^{5}$ National Institute of Biology, Marine Biology Station, Fornace 41. SI-6330 Piran, Slovenia \\ *Corresponding author: E-mail: jadran.faganeli@nib.si, \\ Tel.: +38659232911
}

Received: 12-04-2019

\begin{abstract}
Since arsenic (As) exposure is largely due to geochemical contamination, this study focused on the remediated area of Santana do Morro, a district of Santa Bárbara, Minas Gerais, Brazil, which was previously contaminated with As due to gold mining. Total As concentrations in sediment, soil and plants were determined, next to As species, anionic arsenic compounds As(III), As(V), monomethylarsonic acid (MMA) and dimethylarsinic acid (DMA), in plants samples. Total As concentrations in soil and sediments were slightly elevated $\left(16-18 \mu \mathrm{g} \mathrm{g}^{-1}\right)$ and most of the plants contained low levels of As $\left(<1 \mu \mathrm{g} \mathrm{g}^{-1}\right)$. The exception was a native plant Eleocharis geniculata (L.) which contained elevated levels of As (4 $\mu \mathrm{g} \mathrm{g}^{-1}$ ). The exposure of this plant to As under controlled conditions (hydroponics) indicated its possible tolerance to elevated As levels and suggesting its potential use in phytomonitoring of As-contaminated sites. This plant is able to metabolize arsenate to arsenite and contained MMA and DMA, both in its natural habitat and under controlled conditions.
\end{abstract}

Keywords: Arsenic species; soil; sediments; plants; Cyperacea; Iron Quadrangle

\section{Introduction}

The presence of arsenic (As) in soil, water, plants and food presents a potential risk to human health ${ }^{1,2}$ due to its toxicity. Due to its potential risk, As is considered as one of the most toxic elements to human health according to the ATSDR Substance Priority List ${ }^{3}$ and has received special attention worldwide. ${ }^{4}$ The toxicity and bioavailability of As in the environment depend not only on total concentration, but also on chemical species. In soil, As is relatively immobilized due to insoluble complexes with iron and aluminum oxides. ${ }^{5}$ Generally, the toxicity decreases in the order $\mathrm{As}^{3+}$ inorganic compounds $>\mathrm{As}^{5+}$ inorganic compounds $>\mathrm{As}^{3+}$ organic compounds $>\mathrm{As}^{5+}$ organic compounds. The order of their phytotoxicity is less clear and may be plant species dependent. Finnegan and $\mathrm{Chen}^{6}$ reported that "no As form appears to be consistently most phytotoxic".

In Brazil, the most significant presence of As is restricted to the state of Minas Gerais, specifically in the Iron 
Quadrangle region and in the city of Paracatu. The Iron Quadrangle is a known gold-producing area, where As commonly occurs as arsenopyrite (FeAsS) and as a trace element in pyrite associated with gold mineralization. ${ }^{7}$ In this region, there are many active and abandoned gold mines where the As:Au ratios range from 300 to 3000 . In this region, As is also present due to past anthropogenic activities, when it was discharged into drainage systems and stored in tailing piles on the banks of several local rivers. ${ }^{1,8}$ Large dams have recently been built to store the tailings and the effluents are treated in compliance with environmental regulations since most of the mining and smelting operations, apart from some small-scale mining operations (garimpo), are carried out by large companies with modern infrastructures and facilities. ${ }^{8}$ The spring water, previously used by local inhabitants, was contaminated with As prevalently bonded onto soil particulates. In 2007, water treatment plants were constructed and water became potable. ${ }^{9}$

Various studies related to the Iron Quadrangle have described the environmental impact of As pollution from several old gold mines on stream sediments, surface water and run-off water. The impact of As pollution on the population of the municipalities of Santa Bárbara and Nova Lima ${ }^{1,8,10,11}$ has also been detected in the frame of ARSENEX project. ${ }^{12}$ Results showed that As in soil ranges from between 13-467 $\mathrm{mg} \mathrm{kg}^{-1}$.
In this study, levels of As and its species were determined in soil, sediments and some plants from Santana do Morro, district of Santa Bárbara, to assess the level of As contamination in this remediated area. The main objective of the study was to evaluate if certain plants are able to methylate $\mathrm{As}^{5+}$ and if they can be potential accumulators of As and used in phytomonitoring of As-contaminated sites.

\section{Materials and Methods}

\section{1. Study Area}

Samples were collected in the surroundings of the small village of Santana do Morro (Water spring coordinates: $\left.20^{\circ} 1^{\prime} 15^{\prime \prime S} 43^{\circ} 28^{\prime} 79^{\prime \prime} \mathrm{W}\right)$, located in the district of Santa Bárbara, Minas Gerais, Brazil (Fig. 1). This village has approximately 200 inhabitants and lacks basic services. Until 2006, the water supply originated from the local spring contaminated with As (3.3-21.5 $\left.\mu \mathrm{g} \mathrm{L}^{-1}\right) .^{8}$ From 2006 onwards, the water has been treated in the water treatment plant constructed during the ARSENEX project and from there it is distributed to several houses and the As concentration varies between $<0.08$ and $0.64 \mu \mathrm{g} \mathrm{L}{ }^{-1}{ }^{13}$ The climatological, hydrological and geological features of the study area were described by Almeida et al. ${ }^{7}$
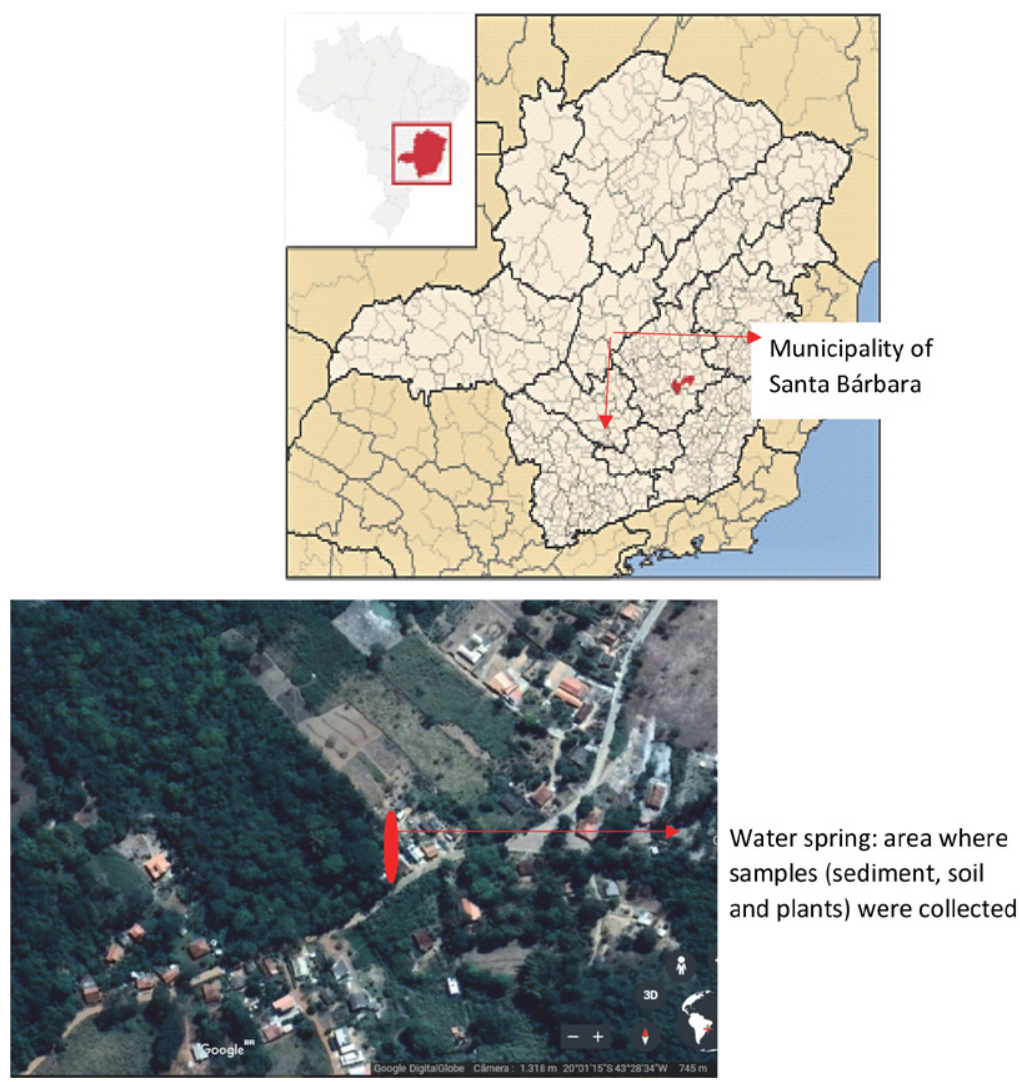

Figure 1. Sampling locations in Santana do Morro (Santa Bárbara district, Minas Gerais, Brazil) (https://earth.google.com/web/@-20.02021163, $43.47656815,739.64086466 \mathrm{a}, 578.07324732 \mathrm{~d}, 35 \mathrm{y}, 0 \mathrm{~h}, 0 \mathrm{t}, 0 \mathrm{r})$ 


\section{2. Collection and Preparation of Soil and Sediment}

Soil samples were taken from surface to the depth of $20 \mathrm{~cm}$ at 14 locations (Fig. 1) in the vicinity where plants were collected. From each location approximately $100 \mathrm{~g}$ of soil was sampled and stored in plastic bags for further analysis. Sediment samples were collected from 14 locations at the edge of the spring pool (Fig. 1) and were also stored in plastic bags. Soil and sediment samples were airdried, homogenized and sieved to five granulometric fractions. The finest-grained fraction $(<0.06 \mathrm{~mm})$ was analyzed after rehomogenization.

\subsection{Collection and Preparation of Plants}

A total of 14 species (Table 1) were collected in the vicinity of the spring pool in Santana do Morro (Fig. 1). One part of the plants sampled was set aside for taxonomical identification and the other part was used for As determination and speciation. The samples for plant identification were stored in paper and pressed. For chemical analysis, all plants collected were first vigorously washed with tap water, immersed in deionized water for some minutes, air dried and weighed. Plant samples were successively frozen, freeze-dried and weighed again. Dried plants were ground to a fine powder in a laboratory mill (Knife Mill GRINDOMIX GM 200, Retsch) and analyzed for As as described below.

\section{4. As Exposure Study of Eleocharis Geniculata}

After identifying the plant which contained As in the environmental survey, a Cyperacea Eleocharis geniculata (L.) was exposed to As in a hydroponic system according to a procedure described by Moreno-Jimenez at al. ${ }^{14}$ Seedlings from the field were grown in a vessel with nutrient solution with commercial fertilizers prepared according to instructions (SUPERthrive ${ }^{\circledR}$, a highly concentrated non-toxic vitamin solution suited for hydro-seeding, hydroponics and foliar spraying) without As. After producing several seedlings in As-free conditions, these seedlings were transferred to a container with fresh commercial nutrient solution and $50 \mu \mathrm{g}$ of $\mathrm{As}(\mathrm{V})$ per container. Ten plastic containers (capacity of $2 \mathrm{~L}$ each) were prepared, each one containing 3 seedlings. After one month of growth, the plants were cleaned by washing them with tap water, followed by immersion in deionized water for several minutes. The roots were separated from the shoots (leaves and stems), compounding two samples, one of shoots (22.97 g dry weight) and one of roots (3.43 g dry weight). This material was frozen, freeze-dried, homogenized and analyzed for total As and its species as described below.

\subsection{Determination of As and its Species}

Determination of total As in soil, sediment and plants The $k_{0}$-INAA method (Instrumental Neutron Activation Analysis) was applied to determine total As concentrations. After being weighed in polyethylene vials suitable for neutron irradiation, the samples were co-irradiated in a TRIGA Mark II reactor together with flux monitor disks of $\mathrm{Al}-0.1 \% \mathrm{Au}$ from the Central Bureau for Nuclear Measurements, Geel, Belgium. After a suitable cooling time the gamma spectra were obtained in a HPGe gamma counting system with $40 \%$ efficiency ${ }^{15,16}$ and evaluated by HyperLab software. ${ }^{17}$ Concentrations were calculated using the Kayzero software. ${ }^{18}$ Standard Reference Materials from the National Research Centre for CRM (China) (GBW 07604, Poplar Leaves, $0.4 \pm 0.1 \mathrm{mg} \mathrm{kg}^{-1}$, certified $0.37 \pm 0.06 \mathrm{mg}$ $\mathrm{kg}^{-1}$ ) and the International Atomic Energy Agency (IAEASOIL-7, $13 \pm 1 \mathrm{mg} \mathrm{kg}^{-1}$, certified $13.4 \pm 0.85 \mathrm{mg} \mathrm{kg}^{-1}$ ) were analyzed together with our samples to verify the accuracy of the $k_{0}$-method. Detection limits were in a range of few ng $\mathrm{g}^{-1}$.

Determination of As species in plant samples Powdered plant samples were extracted with $25 \mathrm{~mL}$ of a Milli-Q water/methanol mixture $(1: 1)$ at $25^{\circ} \mathrm{C}$ for $3 \mathrm{~h}$. After extraction the samples were centrifuged, decanted and re-extracted using the same conditions. Both extracts were joined and evaporated to dryness using a rotary evaporator $\left(45^{\circ} \mathrm{C}, \sim 30 \mathrm{~min}\right)$. Dry residue was taken up into 2.00 $\mathrm{mL}$ of Milli-Q water, filtered through a $0.45 \mu \mathrm{m}$ membrane PVDF syringe filter and kept frozen until analysis. An HPLC-HG-AFS (high performance liquid chromatography-hydride generation - atomic fluorescence spectroscopy) system ${ }^{19}$ was used for determination of the anionic arsenic compounds As(III), As(V), monomethylarsonic acid (MMA) and dimethylarsinic acid (DMA) in extracts. An anion exchange column (Hamilton PRP X-100, with 15 mmol L-1 $\mathrm{KH}_{2} \mathrm{PO}_{4}, \mathrm{pH}$ 6.1) was used to separate compounds prior to hydride generation $\left(4.4 \mathrm{~mol} \mathrm{~L}^{-1} \mathrm{HCl}, 3.0\right.$ $\mathrm{mL} \mathrm{min}^{-1}$ and $1.5 \% \mathrm{NaBH}_{4}$ in $0.1 \% \mathrm{NaOH}, 3 \mathrm{~mL} \mathrm{~min}^{-1}$ ). An Excalibur (PS Analytical, Kent, UK) AFS detector was used for the detection of volatile arsenic hydrides. Detection limits were $1 \mu \mathrm{g} \mathrm{kg}^{-1}$ for MMA and As(III) and $2 \mu \mathrm{g}$ $\mathrm{kg}^{-1}$ for DMA and As(V).

\section{Results and Discussion}

\section{1. Total As in Soil and Sediments}

The mean As concentrations in soil $\left(16 \mathrm{mg} \mathrm{kg}^{-1}\right)$ and sediment $\left(18 \mathrm{mg} \mathrm{kg}^{-1}\right)$ in the vicinity of the spring water pool showed slight contamination. According to Brazilian legislation regarding soil ${ }^{20}$ they were close to prevention values $\left(15 \mathrm{mg} \mathrm{kg}^{-1}\right)$ but below the levels for residential use $\left(55 \mathrm{mg} \mathrm{kg}{ }^{-1}\right.$ ). However, the concentrations were higher than the average values for world soils $\left(5 \mathrm{mg} \mathrm{kg}^{-1}\right)$ but comparable to average values for world sediments (2-22 
mg kg $\left.{ }^{-1}\right) \cdot{ }^{21}$ According to Adriano ${ }^{22}$, As concentrations typically vary from below $10 \mathrm{mg} \mathrm{kg}^{-1}$ in uncontaminated to as high as $30000 \mathrm{mg} \mathrm{kg}^{-1}$ in contaminated world soils. It appears therefore that mining activities did not greatly contribute to As levels in local soil and sediments. ${ }^{23}$

\section{2. Total As in Plants}

The taxonomic determination of the dominant species (Table 1) in the vicinity of the spring water was performed to characterize the vegetation and identify species that might be able to accumulate or exclude As. Only E. geniculata, ${ }^{24,25}$ a wetland annual or short-lived perennial plant commonly known as spike rush, was identified as a native species. Most of the plants investigated contained no detectable As concentrations, as may be expected for unexposed plants. ${ }^{22,26}$ Only E. geniculata contained higher levels of As, i.e. $4 \mathrm{mg} \mathrm{kg}^{-1}$, suggesting that this species is likely tolerant or able to accumulate As. The rather low As concentrations in plant can be associated with rather low As levels in the corresponding soil $\left(16 \pm 1 \mathrm{mg} \mathrm{kg}^{-1}\right)$ and sediment $\left(18 \pm 1 \mathrm{mg} \mathrm{kg}^{-1}\right)$.

E. geniculata is known to be metal-tolerant and its metal accumulation ability was previously confirmed for lead ${ }^{27}$ but there are no data for As. Cyperaceae family is widely distributed around the world and some of the species of Eleocharis genus were suggested to be of potential use in aquatic weed management and pollution abatement $^{28}$. For example, Eleocharis $s p$., naturally colonizing abandoned copper - tailings ponds at the Rakha mines in India, was found to accumulate copper up to $1493 \mathrm{mg} \mathrm{kg}^{-1}$ dry weight, with greater amounts in roots than in shoots. ${ }^{29}$ The potential for accumulation of various metals, i.e. $\mathrm{Cu}$, $\mathrm{Zn}, \mathrm{As}, \mathrm{Pb}, \mathrm{Cd}$, and phytoremediation was reported for Eleocharis acicularis in laboratories and field experiments $^{30,31}$ and for Eleocharis equisetina in an abandoned acid mine tailing pond in NE Australia. ${ }^{32}$ Experiments with As performed with Eleocharis macrostachya revealed that a part of As can be removed from water by rhizofiltration. ${ }^{33}$

\section{3. As Species in Native and Cultivated Eleocharis Geniculata}

Once it was verified that E. geniculata can accumulate more As than other plants, a systematic study of As uptake was performed. Table 2 shows the results of total As and its species determined in roots and shoots of E. geniculata collected in its natural habitat at the spring water pool and in samples after 30 days of cultivation in As enriched nutrient solution in a hydroponic system. Extractability of As from E. geniculata grown in the field or after hydroponic exposure to $\mathrm{As}(\mathrm{V})$ was rather low, $30 \%$ from roots and approximately $60 \%$ from shoots, as is often in plant material. ${ }^{4}$

Samples of E.geniculata from the field contained more total As in the roots than in the shoots. The root:shoot ratio was 16.4 , which is comparable to data from the literature regarding other plants from the same family. For example, E. equisetina contained from $10-146 \mu \mathrm{g} \mathrm{kg}^{-1} \mathrm{As}$ in roots and from 3.3-17.3 $\mu \mathrm{g} \mathrm{kg}^{-1}$ As in shoots ${ }^{32}$ and $E$. macrostachya contained 17-47 times more As in roots compared to shoots. ${ }^{33}$ This similarity indicates that all three plant species are able to exclude As from aboveground tissues. Poor translocation might be the result of sequestration of As into vacuoles of the root cells, helping the plant to alleviate the potentially toxic effects of As. ${ }^{34}$ However, such comparisons could be misleading due to differences in exposure conditions. Sequestration into vacuoles of the root cells during exposure to low levels is likely more efficient than at high levels of As exposure.

As speciation in the E.geniculata samples highlighted the presence of mainly As(III) and small amounts of As(V) and MMA in roots while shoots from the pilot parallel ex-

Table 1. Total arsenic in freeze dried plants collected around the spring water pool in Santana do Morro

\begin{tabular}{llc}
\hline Species & Family & As $\left(\mathbf{m g ~ k g}^{-\mathbf{1}}\right)$ \\
\hline Baccharis retusa DC. & Asteraceae & $<1$ \\
Baccharis calvescens DC. & Asteraceae & $<1$ \\
Cyrtocymura scorpioides (Lam.) H. Rob. & Asteraceae & $<1$ \\
Jacquemontia rufa (Choisy) Hallier f. & Convolvulaceae & $<1$ \\
Eleocharis geniculata (L.) Roem. \& Schult. & Cyperaceae & 4 \\
Rhynchospora marisculus Lindl. \& Nees & Cyperaceae & $<1$ \\
Hyptis lanceolata Poir. & Lamiaceae & $<1$ \\
Hyptis suaveolens Poit. & Lamiaceae & $<1$ \\
Triunfetta semitriloba Jacg. & Malvaceae & $<1$ \\
Rhynchanthera grandiflora (Aubl.) DC. & Melastomataceae & $<1$ \\
Trembleya parviflora (D. Don) Cogn. & Melastomataceae & $<1$ \\
Ludwigia lagunae (Morong) H. Hara & Onagraceae & $<1$ \\
Melinis minutiflora P. Beauv. & Poaceae & $<1$ \\
Borreria capitata (Ruiz \& Pav.) DC. & Rubiaceae & \\
\hline
\end{tabular}

Menezes et al.: Arsenic in Sediments, Soil and Plants ... 
Table 2. Arsenic and its species in Eleocharis geniculata from its natural habitat and cultivated in a hydroponic system with the addition of As(V)

\begin{tabular}{|c|c|c|c|c|c|c|}
\hline Sample & $\begin{array}{l}\text { Part of the } \\
\text { plants }\end{array}$ & $\begin{array}{l}\text { Total As } \\
\left(\mathrm{mg} \mathrm{kg}^{-1}\right)\end{array}$ & $\begin{array}{c}\operatorname{As}(\mathrm{III}) \\
\left(\mathrm{mg} \mathrm{kg}^{-1}\right)\end{array}$ & $\begin{array}{c}\text { DMA } \\
\left(\mathrm{mg} \mathrm{kg}^{-1}\right)\end{array}$ & $\begin{array}{c}\text { MMA } \\
\left(\mathrm{mg} \mathrm{kg}^{-1}\right)\end{array}$ & $\begin{array}{c}\operatorname{As}(\mathrm{V}) \\
\left.(\mathrm{mg} \mathrm{kg})^{-1}\right)\end{array}$ \\
\hline From natural & Roots & $\begin{array}{c}4.6 \\
\pm 0.2\end{array}$ & $\begin{array}{c}0.79 \\
\pm 0.03\end{array}$ & $<0.001$ & $\begin{array}{c}0.005 \\
\pm 0.001\end{array}$ & $\begin{array}{c}0.010 \\
\pm 0.001\end{array}$ \\
\hline habitat $(\mathrm{n}=5)$ & Shoots & $\begin{array}{c}0.28 \\
\pm 0.05\end{array}$ & $\mathrm{Na}$ & $\mathrm{Na}$ & $\mathrm{Na}$ & $\mathrm{Na}$ \\
\hline $\begin{array}{l}\text { From hydroponic } \\
\text { system }\end{array}$ & Roots & $\begin{array}{r}11.5 \\
\pm 0.4\end{array}$ & $\begin{array}{l}2.67 \\
\pm 0.08\end{array}$ & $\begin{array}{l}0.09 \\
\pm 0.01\end{array}$ & $\begin{array}{l}0.05 \\
\pm 0.01\end{array}$ & $\begin{array}{c}1.64 \\
\pm 0.11\end{array}$ \\
\hline$(\mathrm{n}=5)$ & Shoots & $\begin{array}{l}25 \\
\pm 1\end{array}$ & $\begin{array}{c}4.55 \\
\pm 0.16\end{array}$ & $\begin{array}{c}0.39 \\
\pm 0.06\end{array}$ & $\begin{array}{c}0.06 \\
\pm 0.01\end{array}$ & $\begin{array}{c}9.62 \\
\pm 0.87\end{array}$ \\
\hline
\end{tabular}

$\mathrm{Na}$ - not analyzed due to insufficient mass

periment also contained low but detectable amounts of DMA (data not shown). It is known that $\mathrm{As}(\mathrm{V})$ is readily reduced to As(III) by plants, while biomethylation issues are less clear ${ }^{35}$ and attributed to microorganisms, in particular bacteria living in soil. ${ }^{35}$

In the hydroponic system, the seedling was subjected to a total of $500 \mu \mathrm{g}$ of $\mathrm{As}(\mathrm{V})$ for one month and the growing plants took up all the available As. In the hydroponic system (absence of soil), the roots contained less As than shoots, which is contradictory to natural conditions and possibly related to different exposure condition ${ }^{35}$ including additional exposure to higher concentrations in a shorter time. In such conditions the plant was able to translocate As from roots to shoots very efficiently. It is believed that in the tolerant plants a much higher amount of assimilated As is transported to the shoots than in nontolerant plants. ${ }^{36}$ Concerning the species studied, the results also showed the presence of As(III), pointing out the ability of the plant to metabolize As(V) to As(III) as previously observed by Finnegan and $\mathrm{Chen}^{6}$ and to produce MMA and DMA. All four arsenic species were identified in roots and shoots. In the same plants growing in the field we identified three arsenic species, without DMA, in roots only. Involvement of bacterial methylation of As could not be excluded since we did not use axenic conditions. Arsenosugars and other arsenic species were not detected in any of the samples.

\section{Conclusions}

Total As concentrations in soil and sediments in a remediated area in Santana do Morro, a district of Santa Bárbara, Minas Gerais, Brazil, were slightly elevated (16$\left.18 \mu \mathrm{g} \mathrm{g}^{-1}\right)$ but most plants contained low levels of As $(<1$ $\left.\mu \mathrm{g} \mathrm{g}^{-1}\right)$. The analysis of vegetation, mostly consisting of alien species, showed that only E. geniculata, a native plant, contained elevated levels of As. E.geniculata exposed to As in its habitat and to inorganic As $\left(\mathrm{As}^{5+}\right)$ under controlled conditions (hydroponic system) was able to accumulate
As. As from the treatment solution was removed completely suggesting its potential use in phytomonitoring and removing As from contaminated soils ${ }^{37}$ and further exploration is suggested. This plant was able to metabolize $\mathrm{As}(\mathrm{V})$ to $\mathrm{As}(\mathrm{III})$ and produced minor amounts of MMA and DMA in both situations.

\section{Acknowledgements}

The authors wish to thank Prof. Alexandre Salino and colleagues, the Botanic Department, Institute for Biological Sciences, Federal University of Minas Gerais (UFMG) for floristic analysis. This study was financially supported by CNPq (National Counsel of Technological and Scientific Development), Process n. 490059/2009-0 (Edital CNPq N 015/2009) and by the Slovenian Research Agency (ARRS) through Slovenian-Brazilian scientific cooperation (BI-BR/10-12-002).

\section{References}

1. E. Smith, R. Naidu, A. M. Alston, Adv. Agron. 1998, 64, 149195. DOI:10.1016/S0065-2113(08)60504-0

2. A. L. Juhasz, E. Smith, J. Weber, M. Rees, A. Rofe, T. Kuchel, L. Sansom, R. Naidu, Chemosphere 2008, 71, 1963-1969.

DOI:10.1016/j.chemosphere.2007.12.021

3. ATSDR, Agency for Toxic Substances \& Disease Registry, http://www.atsdr.cdc.gov/spl/, 2013.

4. A. Sarkar, B. Paul, Chemosphere 2016, 158, 37-49.

DOI:10.1016/j.chemosphere.2016.05.043

5. I. Arčon, H. J. Van Elteren, A. Glass, A. Kodre, Z. Šlejkovec, X-Ray Spectrom. 2005, 34, 435-438.

DOI: $10.1002 / \mathrm{xrs} .857$

6. P. M. Finnegan, W. Chen, Front. Physiol. 2012, 3, 182, doi. org./10.3389/fphys.2012.00182.

7. K. Almeida, J. Matschullat, J. Mello, I. Meneses, Z. Viola, in: E. Deschamps, J. Matschullat (Ed.): Arsenic: Natural and Anthropogenic, CRC Press, Boca Raton, 2011, pp. 81-90.

8. O. Vasconcelos, S. Oberda, E. Deschamps, J. Matschullat, in: 
E. Deschamps, J. Matschullat (Ed.): Arsenic: Natural and Anthropogenic, CRC Press, Boca Raton, 2011, pp. 119-126.

DOI:10.1201/b10772-15

9. E. Deschamps, N. Assuncao, in: E. Deschamps, J. Matschullat (Ed.): Arsenic: Natural and Anthropogenic, CRC Press, Boca Raton, 2011, pp. 183-192. DOI:10.1201/b10772-21

10. L. V. Cruz, Avaliação Geoquímica ambiental da Estação Ecológica do Tripuí e adjacências, sudeste do Quadrilátero Ferrífero, MG. Universidade Federal de Ouro Preto, M.Sc. Thesis, 2002.

11. J. Matschullat, R. P. Borba, E. Deschamps, B. R. Figueiredo, T. Gabrio, M. Schwenk, Appl. Geochem. 2000, 15, 181-190. DOI:10.1016/S0883-2927(99)00039-6

12. N. Couto, S. Mattos, J. Matschullat, in: E. Deschamps, J. Matschullat (Ed.): Arsenic: Natural and Anthropogenic, CRC Press, Boca Raton, 2011, pp. 153-167.

13. C. A. Ferreira, H. E. L. Palmieri, M. Â. B. C. Menezes, L. M. L. A. Auler, Amer. Jour. Water Res. 2017, 5, 29-40.

14. E. Moreno-Jimenez, E. Esteban, T. Fresno, C. Lopez de Egea, J. M. Penalosa, Chemosphere 2010, 79, 513-517. DOI:10.1016/S0883-2927(99)00039-6

15. R. Jaćimović, V. Stibilj, L. Benedik, B. Smodiš, Jour. Radioanal. Nucl. Chem. 2003, 257, 545 - 549.

DOI:10.1023/A:1025484313986

16. M. Â. B. C. Menezes, R. Jaćimović, Jour. Radioanal. Nucl. Chem. 2008, 278, 607-611.

DOI:10.1007/s10967-008-1201-x

17. HyperLab. System. Installation and Quick Start Guide, HyperLabs Software, Budapest, Hungary, 2009.

18. Kayzero for Windows ${ }^{\circledR}$ User's Manual, for reactor neutron activation analysis (NAA) using the $k_{0}$ standardisation method, Ver. 2.42, 2008.

19. Z. Šlejkovec, J. T van Elteren, H. J. Glass, Z. Jeran, R. Jaćimović, Int. Jour. Environ. Anal. Chem. 2010, 90, 784-796. DOI:10.1080/03067310902977542

20. Brasil. Conselho Nacional de Meio Ambiente - CONAMA, Resolução 420/2009, de 28 de dezembro de 2009. "Dispõe sobre critérios e valores orientadores de qualidade do solo quanto à presença de substâncias químicas e estabelece diretrizes para o gerenciamento ambiental de áreas contaminadas por essas substâncias em decorrência de atividades antrópicas”, Brasília. 2009.

21. C. Reimann, P. de Caritat, Chemical elements in the envi- ronment Factsheets for the geochemists and environmental scientists, Springer, New York, 1998.

22. D. C. Adriano, Trace Elements in the Terrestrial Environment. Springer, New York, 2001.

DOI:10.1007/978-0-387-21510-5

23. E. Deschamps, J. Meillo, J. Matschullat, in: E. Deschamps, J. Matschullat (Ed.): Arsenic: Natural and Anthropogenic, CRC Press, Boca Raton, 2011, pp. 127-139. DOI:10.1201/b10772

24. M. L. L. Martins, R. M. Carvalho-Okano, M. Luceño, Acta Bot. Bras. 1999, 13, 187-222. DOI:10.1590/S0102-33061999000200008

25. A. S. B. Gil, C. P. O. Bove, Arq. Mus. Nac. Rio de Janeiro 2004, 62, 131-150.

26. R. Eisler, Eisler's Encyclopedia of Environmentally Hazardous Priority Chemicals, Elsevier, 9999Amsterdam, 2007.

27. J. Yang, Z. Ye, Environ. Sci. Pollut. Res. 2015, 22, 1931-1939. DOI:10.1007/s11356-014-3610-4

28. M. S. Gonzales-Elizondo, P. M. Peterson, Taxon 1997, 46, 433-449. DOI:10.2307/1224386

29. M. Das, S. K. Maiti, Land Contam. Reclam. 2008, 16, 135-153. DOI:10.2462/09670513.691

30. M, Sakahibara, Y. Ohmori, N. T. H. Sano, K. Sera, Clean - Soil, Water 2011, 39, 735-741. DOI: $10.1002 /$ clen.201000488

31. A. G. Nurfitiri, S. Masayuki, S. Koichiro, Environ. Sci. Ind. Jour. 2017, 13, 131.

32. B. A. Lottermoser, P. A. Ashley, Environ. Pollut. 2011, 159, 3028-3035. DOI:10.1016/j.envpol.2011.04.014

33. M. A. Olmos-Márquez, M. T. Alarcón-Herrera, I. R. MartínDomínguez, Environ. Sci. Pollut. Res. 2012, 19, 763-771. DOI:10.1007/s11356-011-0598-x

34. A. K. Shankar, C. Cervantes, H. Loza-Tavera, S. Avudainayagam, Sci. Total Environ. 2005, 31, 739-753.

DOI:10.1016/j.envint.2005.02.003

35. P. Wang, G. Sun, Y. S. Jia, A. A. Meharg, Y. Zhu, Jour. Environ. Sci. 2014, 26, 371-381. DOI:10.1016/S1001-0742(13)60432-5

36. N. Singh, L. Q. Ma, in: N. Willey (ed.): Phytoremediation: Methods and Reviews, Biotechnology, Humana Press, Totowa, 2007.

37. L. Q. Ma, K. M. Komar, C. Tu, W. Zhang, Y. Cai, E. D. Kennelley, Nature, 2001, 409, 579. DOI:10.1038/35054664 


\section{Povzetek}

V področju kontaminiranem z arzenom (As) Santana do Morro (Santa Bárbara, Minas Gerais, Brazilija), kot posledica rudarjenja zlata, smo določili koncentracije celotnega As v sedimentu, prsti in rastlinah. V rastlinah smo analizirali tudi zvrsti As: As(III), As(V), metilarzonsko (MMA) in dimetilarzinsko kislino (DMA). Koncentracije As v prsti in sedimentu so bile le rahlo povečane $\left(16-18 \mu \mathrm{g} \mathrm{g}{ }^{-1}\right)$ in večina rastlin je vsebovala nizke koncentracije As $\left(<1 \mu \mathrm{g} \mathrm{g} \mathrm{g}^{-1}\right)$. Izjema je bila avtohtona rastlina Eleocharis geniculata (L.) s povečanimi koncentracijami As $\left(4 \mu \mathrm{g} \mathrm{g}^{-1}\right)$. Poskusi v kontroliranih pogojih (hidroponika) kažejo na njeno odpornost na povečane koncentracije As in možnost uporabe v fitomonitoringu in bioremediaciji kontaminiranih področij z As. Rastlina metabolizira arzenat v arzenit in vsebuje MMA in DMA v naravnih in laboratorijskih pogojih. 